Case Reports
in Dermatology
Case Rep Dermatol 2020;12:144-149

DOI: 10.1159/000508884

Published online: August 18, 2020

(C) 2020 The Author(s)

Published by S. Karger AG, Basel

www.karger.com/cde

This article is licensed under the Creative Commons Attribution-NonCommercial 4.0 International License (CC BY-NC) (http://www.karger.com/Services/OpenAccessLicense). Usage and distribution for commercial purposes requires written permission.

\title{
Angiosarcoma of the Auricle in a Patient with Xeroderma Pigmentosum Variant
}

\author{
Masazumi Onishi ${ }^{\mathrm{a}}$ Kanako Tsunoda ${ }^{\mathrm{a}}$ Fumihiko Maeda ${ }^{\mathrm{a}}$ \\ Shinichi Moriwaki ${ }^{\text {b Hiroo Amano }}{ }^{a}$ \\ aDepartment of Dermatology, Iwate Medical University School of Medicine, \\ Yahaba-cho, Japan; 'bepartment of Dermatology, Osaka Medical College, \\ Takatsuki, Japan
}

\section{Keywords}

Angiosarcoma $\cdot$ Xeroderma pigmentosum variant $\cdot$ Auricle

\begin{abstract}
Xeroderma pigmentosum (XP) is an inherited autosomal recessive disorder characterized by photosensitivity and an increased risk of developing multiple skin neoplasms at sites exposed to the sun. We report a 73-year-old Japanese man with angiosarcoma of the auricle and an XP-variant, which is a very rare condition. In this case, long-term physical stimulation due to auricular deformation after surgery may have been the cause. Angiosarcoma associated with XP has a better prognosis than common angiosarcoma, perhaps because of the smaller tumor size. As XP patients are at high risk of skin neoplasms, they consult dermatologists regularly, and therefore skin tumors are likely to be detected early.

(C) 2020 The Author(s)

Published by S. Karger AG, Basel
\end{abstract}




\section{Case Reports in Dermatology}

Case Rep Dermatol 2020;12:144-149

DOI: $10.1159 / 000508884$

(c) 2020 The Author(s). Published by S. Karger AG, Basel www.karger.com/cde

Onishi et al.: Angiosarcoma with XP-Variant

\section{Introduction}

Xeroderma pigmentosum (XP) is an inherited autosomal recessive disorder characterized by photosensitivity and an increased risk of developing multiple skin neoplasms at sites exposed to the sun. Basal cell carcinoma, squamous cell carcinoma and malignant melanoma associated with XP are common, but cases of cutaneous angiosarcoma are rare. Angiosarcoma is a rare related malignant skin neoplasm with a high rate of local recurrence. Angiosarcomas represent only $2 \%$ of all sarcomas and arise from vascular endothelial cells [1]. Several cases of angiosarcoma associated with XP have been reported. Here we review these previous reports with reference to a case of auricular angiosarcoma associated with XP.

\section{Case Report}

A 73-year-old Japanese man who had had repeated skin neoplasms such as basal cell carcinoma, squamous cell carcinoma, and melanoma in sun-exposed areas for 30 years presented to our hospital. He had a diagnosis of xeroderma pigmentosum variant (XP-V) 10 years ago based on the examination of unscheduled DNA synthesis and post-UV colony formation assay in the presence or absence of caffeine. A genetic analysis revealed that a homozygous mutation c.1066C $>$ T in POLH in exon 9 was identified in this patient.

There was a family history of XP; his brother had a diagnosis of XP-V and had been treated for basal cell carcinoma. The patient presented to our hospital with a bleeding tumor of the left auricle. Physical examination revealed a $1.9 \times 1.8 \mathrm{~cm}$ diameter erythematous ulcerated plaque on the left helix to anthelix, and superior helix missing for resection of the basal cell carcinoma (Fig. 1a). A positron emission tomography revealed an abnormal accumulation in his left ear. A histopathological examination demonstrated that the lesion was composed of atypical endothelial cells with markedly hyperchromatic pleomorphic nuclei in the dermis, forming an undifferentiated vascular structure (Fig. 1b). The tumor cells were positive for CD31, CD34 and D2-40. Based on these findings, we diagnosed the patient as having angiosarcoma. We performed wide local excision with a $10-\mathrm{mm}$ margin. He had complete resection and no sign of recurrence after 15 months.

\section{Discussion}

Fifty percent of all angiosarcomas involve the skin of the head and neck, whereas auricular involvement is very rare. To our knowledge, only 7 cases of auricular angiosarcoma, including the present case, have been reported (Table 1) [2-7]. The patients comprised 4 males and 3 females, with a wide age range (31-90 years). We were unable to confirm any pre-existing or underlying disease in common, which could have contributed to angiosarcoma development, although one case occurred after modified radical mastoidectomy for cholesteatoma. It is conceivable that chronic otitis might be a sarcoma risk factor [2]. As one case of middle-ear angiosarcoma was associated with chronic otorrhea [8], chronic inflammation may lead to the onset of auricular angiosarcoma. In the majority of the patients whose courses and treatment were described, wide surgical resection was performed. Some patients 


\section{Case Reports in Dermatology}

Case Rep Dermatol 2020;12:144-149

DOI: $10.1159 / 000508884$

(C) 2020 The Author(s). Published by S. Karger AG, Basel www.karger.com/cde

Onishi et al.: Angiosarcoma with XP-Variant

underwent postoperative radiation therapy. One case of angiosarcoma that appeared on the auricle after radiation therapy was noteworthy [6]. Although these patients showed an uneventful course without further development, only a short-term follow-up was performed, and therefore the long-term outcome was uncertain.

A similar report from the Republic of Korea documented 11 cases of cutaneous angiosarcoma complicated by XP [9]. To our knowledge, only 3 cases of angiosarcoma in XP-V patients have been reported (Table 2) [9-11]. Most cases occurred on the face and head, as is common for angiosarcoma. In most cases, the tumor was $<5 \mathrm{~cm}$ in size. Wide surgical resection was performed, and 1 patient received preoperative radiation therapy [9]. It remains to be clarified whether radiation, like ultraviolet rays in XP, affects DNA damage repair function. There has been no documented case of angiosarcoma in XP patients occurring after radiotherapy, although further study of the effect of radiation in XP patients is required. Angiosarcoma has a high rate of local recurrence. A previous study has reported a poor 5-year survival rate in angiosarcoma patients (38\%) [12]. The preferred treatment for angiosarcoma in XP patients is mostly wide surgical resection alone; no cases of local recurrence or distant metastasis have been reported [9]. This may have been due to the brief follow-up period, although in most cases the tumor was $<5 \mathrm{~cm}$ in size. A previous meta-analysis showed that patients with tumors $<5 \mathrm{~cm}$ in size had a higher 5-year survival rate than those with tumors measuring $>5 \mathrm{~cm}$ [12]. Furthermore, XP patients were regularly attending hospitals since they were at risk of multiple skin neoplasms. Therefore, early treatment was possible when malignancy was suspected.

As the present case of angiosarcoma arose in a sun-exposed area, we assumed that UVinduced DNA damage had caused the tumor. Generally, skin angiosarcoma arises more commonly in sun-exposed areas, but may also occur as a result of trauma, lymphedema, and radiation exposure. These common sites of skin angiosarcoma correspond roughly to the so-called immunocompromised districts described by Ruocco et al. [13], who considered that they represent areas of peculiar vulnerability to tumors, infections and immune disorders in cutaneous regions that have been affected by chronic lymphoedema, herpetic infections or other heterogeneous forms of injury, such as vaccinations, UV or ionizing radiation, thermal burns, and traumas $[13,14]$. After the causes of these events have disappeared, the affected district may appear clinically normal, but its immune status is often permanently compromised.

Angiosarcoma of the auricle is very rare, and in this patient, it is possible that long-term physical stimulation of a surgical scar representing an immunocompromised district due to auricular deformation might have led to the tumor development. It is necessary to pay attention to the occurrence of angiosarcoma in XP patients, similarly to that of squamous cell carcinoma or basal cell carcinoma.

\section{Statement of Ethics}

Informed consent was obtained from the patient for the publication of this case report and any accompanying images. The study complied with the Declaration of Helsinki. This case report was approved by the ethics bord of the Department of Dermatology, Osaka Medical College (Approval No. 2569). 
Case Reports
in Dermatology

Case Rep Dermatol 2020;12:144-149

DOI: $10.1159 / 000508884$

(c) 2020 The Author(s). Published by S. Karger AG, Basel www.karger.com/cde

Onishi et al.: Angiosarcoma with XP-Variant

\section{Conflict of Interest Statement}

The authors declare no conflict of interest.

\section{Funding Sources}

None of the authors received any financial support for the present study.

\section{Author Contributions}

All authors have contributed significantly. M. Onishi, K. Tsunoda, F. Maeda, and H. Amano took care of the patients. S. Moriwaki performed the genetic analysis. M. Onishi wrote the manuscript. All authors agree with the content of the manuscript.

\section{References}

1 Sharma S, Deshmukh AD, Bal MM, Chaukar DA, Dcruz AK. Angiosarcoma of the scalp associated with Xeroderma pigmentosum. Indian J Med Paediatr Oncol. 2012 Apr;33(2):126-9.

2 Leighton SE, Levine TP. Angiosarcoma of the external ear: a case report. Am J Otol. 1991 Jan;12(1):54-6.

3 Ho TL, Lee HJ, Liu SZ, Zhan HL, Hsu SM. CT scan features of auricular angiosarcoma: a case report. Field Med J. 2009 Feb;4(8):109-13.

4 Issara K, Boughaleb Z, Tawfiq N, Bouchbika Z, Benchakroun N, Jouhadi H, et al. [A case of angiosarcoma of the outer ear]. Pan Afr Med J. 2016 Jun;24:177.

5 Barhmi I, Abada R, Roubal M, Mahtar M. Angiosarcoma of the auricle. Eur Ann Otorhinolaryngol Head Neck Dis. 2016 Sep;133(4):281-2.

6 Figueroa-Silva O, Argenziano G, Lallas A, Longo C, Piana S, Moscarella E. Dermoscopic pattern of radiationinduced angiosarcoma (RIA). J Am Acad Dermatol. 2015 Aug;73(2):e51-5.

7 Gonzalez CD, Hawkes JE, Bowles TL. Recurrent cutaneous angiosarcoma of the ear masquerading as atypical fibroxanthoma. JAAD Case Rep. 2016 Dec;2(6):445-7.

8 Buraïma F, Kouassi YM, Coulibaly A, Touré A, Tanon-anoh MJ, Kouassi B. A case of middle-ear angiosarcoma. Eur Ann Otorhinolaryngol Head Neck Dis. 2011 Apr;128(2):87-9.

9 Hong WJ, Lee SE, Roh MR, Kim JE, Nishigori C, Kim SC. Angiosarcoma arising on the scalp in a Korean patient with xeroderma pigmentosum variant type. Photodermatol Photoimmunol Photomed. 2018 Sep;34(5):3436.

10 De Silva BD, Nawroz I, Doherty VR. Angiosarcoma of the head and neck associated with xeroderma pigmentosum variant. Br J Dermatol. 1999 Jul;141(1):166-7.

11 Marcon I, Collini P, Casanova M, Meazza C, Ferrari A. Cutaneous angiosarcoma in a patient with xeroderma pigmentosum. Pediatr Hematol Oncol. 2004 Jan-Feb;21(1):23-6.

12 Lahat G, Dhuka AR, Hallevi H, Xiao L, Zou C, Smith KD, et al. Angiosarcoma: clinical and molecular insights. Ann Surg. 2010 Jun;251(6):1098-106.

13 Ruocco V, Brunetti G, Puca RV, Ruocco E. The immunocompromised district: a unifying concept for lymphoedematous, herpes-infected and otherwise damaged sites. J Eur Acad Dermatol Venereol. 2009 Dec;23(12):1364-73.

14 Vojvodic A, Tirant M, Nardo VD, Lotti T, Wollina U. Immunocompromised Districts of Skin: A Case Series and a Literature Review. Open Access Maced J Med Sci. 2019 Sep; 10;7(18):2969-75. 


\section{Case Reports in Dermatology}
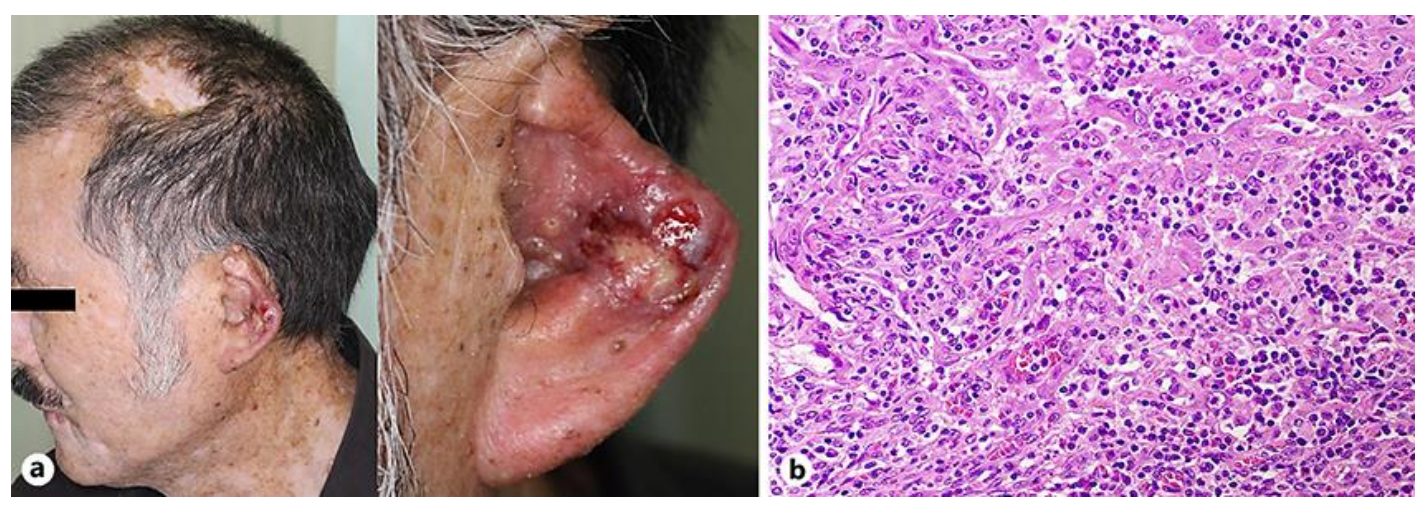

Fig. 1. a Erythematous ulcerated plaque on the left helix to anthelix. b Photomicrograph showing atypical endothelial cells with hyperchromatic markedly pleomorphic nuclei in the dermis, forming undifferentiated vascular structures (HE., original magnification: $\times 200$ ).

Table 1. Summary of reported cases of cutaneous angiosarcoma involvement of the auricle

\begin{tabular}{|c|c|c|c|c|}
\hline Authors/reference & Age & Sex & Treatment & Prognosis \\
\hline Leighton SE et al. [2] & 82 & M & Resection & $\begin{array}{l}12 \text { months later recurrence } \\
\text { RT done } 18 \text { months later no recurrence }\end{array}$ \\
\hline Ho TL et al. [3] & 82 & $\mathrm{~F}$ & $\mathrm{RT}$ & Uncertain \\
\hline Issara K et al. [4] & 31 & $\mathrm{~F}$ & $\begin{array}{l}\text { Resection } \\
(5 \mathrm{~mm}) \\
\text { RT }\end{array}$ & $\begin{array}{l}\text { No recurrence } \\
\text { (12 months) }\end{array}$ \\
\hline Barhmi I et al. [5] & 31 & $\mathrm{~F}$ & Resection RT & $\begin{array}{l}\text { No recurrence } \\
\text { (6months) }\end{array}$ \\
\hline Figueroa-Silva 0 et al. [6] & 90 & M & unceratin & Unceratin \\
\hline Gonzales CD et al. [7] & 65 & $\mathrm{M}$ & $\begin{array}{l}\text { Resection } \\
(10 \mathrm{~mm}) \\
\text { RT }\end{array}$ & $\begin{array}{l}\text { No recurrence } \\
\text { (9months) }\end{array}$ \\
\hline Present case & 73 & M & $\begin{array}{l}\text { Resection } \\
(10 \mathrm{~mm})\end{array}$ & $\begin{array}{l}\text { No recurrence } \\
\text { (15months) }\end{array}$ \\
\hline
\end{tabular}

F, female; M, male; RT, radiation therapy. 
Case Reports in Dermatology
Case Rep Dermatol 2020;12:144-149

DOI: $10.1159 / 000508884$

(c) 2020 The Author(s). Published by S. Karger AG, Basel www.karger.com/cde

Onishi et al.: Angiosarcoma with XP-Variant

Table 2. Summary of reported cases of cutaneous angiosarcoma complicating XP variant

\begin{tabular}{lcccccl}
\hline Authors/reference & Age & Sex & Site & Tumor size & Treatment & Prognosis \\
\hline De Silva et al. [10] & 63 & M & cheek & $1.5 \mathrm{~cm}$ & Resection & $\begin{array}{l}\text { No recurrence } \\
\text { (18 months) }\end{array}$ \\
\hline Marcon I. [11] & 15 & M & nose & $1.5 \mathrm{~cm}$ & Resection & $\begin{array}{l}\text { No recurrence } \\
\text { (40 months) }\end{array}$ \\
\hline Hong W.J. [9] & 65 & M & scalp & $\begin{array}{l}3 \times 4 \mathrm{~cm} \\
1 \times 1.5 \mathrm{~cm}\end{array}$ & $\begin{array}{l}\text { Resection } \\
\text { RT }\end{array}$ & $\begin{array}{l}\text { No recurrence } \\
\text { (54 months) }\end{array}$ \\
\hline
\end{tabular}

F, female; M, male; RT, radiation therapy. 